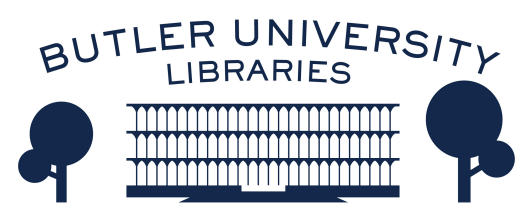

Journal of Hindu-Christian Studies

January 2004

\title{
Book Review: "Christians, Cultural Interactions, and India's Religious Traditions"
}

Harold Coward

Follow this and additional works at: https://digitalcommons.butler.edu/jhcs

Part of the Religion Commons

\section{Recommended Citation}

Coward, Harold (2004) "Book Review: "Christians, Cultural Interactions, and India's Religious Traditions"," Journal of Hindu-Christian Studies: Vol. 17, Article 16.

Available at: https://doi.org/10.7825/2164-6279.1325

The Journal of Hindu-Christian Studies is a publication of the Society for Hindu-Christian Studies. The digital version is made available by Digital Commons @ Butler University. For questions about the Journal or the Society, please contact cbauman@butler.edu. For more information about Digital Commons @ Butler University, please contact digitalscholarship@butler.edu. 
This further, more explicitly theological dialogue can be initiated perhaps by noting how doctrines and practices function in community formation, in shaping believers, over generations, as certain kinds of people. The full dialogue needs to attend to who the believers are and to their basic instincts and sentiments, and for that it needs to preserve a space wherein individuals and communities deepen their own formative learning, while yet learning to engage the formative processes of the other traditions. Making Harmony is a thoughtful and rich entrance into pluralism and dialogue, best understood if we take seriously Amaladoss's claim that harmony will be the place where deeper dialogues and subsequent theological exchanges can then occur.

Francis X. Clooney, S.J. Boston College

\section{Christians, Cultural Interactions, and India's Religious Traditions. Edited by Judith M. Brown and Robert Eric Frykenberg. London: Routledge-Curzon and Wm. B. Eerdmans, 2002, ix +241 pp.}

\begin{abstract}
ALTHOUGH religious pluralism in India was previously examined in Modern Indian Responses to Religious Pluralism, edited by Harold Coward (SUNY Press, 1987), a gap in scholarship has existed in that no focused analysis has been made of how Protestant Christianity has interacted with India's many religious traditions in the modern period. The book under review, which resulted from a conference of scholars from England, Denmark and the United States held at Oxford in 1999, successfully fills that gap. As Judith Brown remarks in her introduction, India's history has been marked by a religious pluralism in which converts to Christianity carried with them much from their former beliefs and cultural practices.
\end{abstract}

Although Syrian Christianity had been in India for centuries, the eighteenth and nineteenth centuries marked a new drive to convert Indians by missionaries arriving from Europe and America. For the first time in India's history, Christianity was the religion of the rulers. Christianity was also strongly present in the new schools set up in India, and through these schools influenced many key leaders of the Indian Renaissance and Independence movements. Thus,
Christianity became a powerful presence and a cultural catalyst in India, especially with the aid of modern printing presses that produced large numbers of books and pamphlets on social and religious issues in English and in India's vernacular languages. Within this context, the essays in this book explore some of the ways Christianity has interacted with India's many religious traditions. The focus on Protestant Christianity is adopted partly because of the connection between Anglicanism and India's Imperial rulers.

The first three chapters deal with the world of "High Culture" among Hindus and Muslims. Although there were few converts to Christianity from among educated, sophisticated Indians of high social standing, these Indians developed an awareness that their traditions were being challenged by Christianity and secular forces from the West. Educated Hindus did not just react but used Christian insights to reinvigorate elements within their own traditions, as Gandhi did in reworking the meaning of themes such as charity and sacrifice. Actions of missionaries in setting up institutions of education and social welfare were emulated by some Hindus in the restructuring of their own traditions - as, for example, by the 
Arya Samaj. Brown notes, "When educated Indians did become Christians, they did not leave behind their cultural inheritance but often used the cultural and devotional resources of their earlier traditions in the expression of their new faith - thus, they contributed to new Indian modes of Christian worship and theological emphasis ..." (p.4). Indira Peterson shows how a Protestant poet in South India used Tamil forms of Hindu devotion to tell a Christian story. Richard Fox Young examines how educated Hindus were drawn into an encounter with Christians and how they viewed missionaries.

The next group of chapters are devoted to Christians within Indian popular culture, highlighting the way Christian converts were deeply embedded in the local religious traditions, region and locality - and how these influences shaped Christian expression. Peter Andersen, Beppe Karlsson and John Webster examine the experience of Dalits and tribals as converts to Christianity. Coming from the base or margins of Hindu society and often being illiterate, it has been difficult for historians to hear their voices except through the filter of missionary accounts which were inevitably colored by their own Western prejudices. Michael Bergunder focuses on popular linguistic interaction as the Protestant Christians translated the Bible into vernacular languages and emphasized the need for literacy. These efforts sometimes became involved in assisting in the flowering of local languages and cultures. This linguistic interaction can go in both directions. Bergunder shows, for example, how Tamil Christianity appropriates certain types of vernacular for key texts of the Bible and is in turn influenced by the cultural trends in the region. This very insightful analysis shows that much more research can be done on these local "translation influences."

Other essays focus on conversion, its meaning and dynamics. In some cases disadvantaged groups were using conversion as a way to find meaning for their lives in times of socioeconomic change. Webster shows how conversions to Christianity led to changes in families and kin groups not just in self-esteem but also in health, education and the prospect of social and economic advancement. Such changes occurred after the bonds that tied converts to the lowliest place in village society were loosened by their interaction with Christianity and its Indian and foreign representatives. Harper's essay examines the formation of new Christian communities and how ill-educated converts were led to refashion their lives so as to become men and women active in church leadership. A challenge to building a truly Indian church involved the question of how to extract converts from some aspects of their Hindu cultural inheritance that were deemed incompatible with Christianity while retaining other aspects that were seen as conducive to Christian living and worship. Studdert-Kennedy examines the further problem of how a "colonial" Anglican Church with its connections to British ruling classes and structures could evolve into a truly Indian church in terms of theology and authority.

The essays in this volume help us to see Christianity, Christians and missionaries in India in the nineteenth and twentieth centuries as a vital part of a broad spectrum of cultural and religious change on the subcontinent.

Harold Coward University of Victoria 